\title{
extrait d'espaces vers
}

\author{
Lola Lemire Tostevin
}

\section{espaces vers vers où?}

vers quoi?

cette rupture qui donne lieu à une syntaxe qui se veut peau sur laquelle se trace un autre sens (une sensation)

à travers le silence (les pulses travaillent en silence) l'organisme se renseigne sur ses éléments extérieurs (tes yeux ta voix tes mains) la mémoire d'un toucher où s'inscrit l'au-delà d'une langue tout en insérant de nouveaux fragments oreilles neuves pour une musique nouvelle

(Toronto, The Coach House Press, 1988, p. 53) 